\title{
Effects of Osmolality and Ionic Strength on Secretion from Adrenal Chromaffin Cells Permeabilized with Digitonin
}

\author{
Ronald W. Holz and Ruth A. Senter \\ Department of Phamacology, University of Michigan Medical School, Ann Arbor, Michigan, U.S.A.
}

\begin{abstract}
Hyperosmotic solutions inhibit exocytosis of catecholamine from adrenal chromaffin cells at a step after $\mathrm{Ca}^{2+}$ entry into the cells. The possibility that the inhibition resulted from an inability of shrunken secretory granules to undergo exocytosis was investigated in cells with plasma membranes permeabilized by digitonin. The osmoticants and salts used in this study rapidly equilibrated across the plasma membrane and bathed the intracellular organelles. When sucrose was the osmoticant, secretion was not significantly inhibited unless the osmolality was raised above $1,000 \mathrm{mOs}$. When the osmolality was raised with the tetrasaccharide stachyose or a low-molecular-weight maltodextrin fraction (average size a tetrasaccharide), one-half maximal inhibition occurred at $900-1,000 \mathrm{mOs}$. Prior treatment of permeabilized cells with $\mathrm{Ca}^{2+}$ in hyperosmotic solution did not result in enhanced secretion when cells were restored to normal osmolality. Increased concentrations of potassium glutamate or sodium isethionate were more potent than carbohydrate in inhibiting secretion. Half-maximal inhibition occurred at $600-700 \mathrm{mOs}$ or when the ionic strength was approximately doubled. The inhibition by elevated potas-
\end{abstract}

sium glutamate also occurred when the osmolality was kept constant with sucrose. Increasing the ionic strength did not alter the $\mathrm{Ca}^{2+}$ sensitivity of the secretory response. Reducing the ionic strength by substituting sucrose for salt reduced the $\mathrm{Ca}^{2+}$ concentration required for half-maximal stimulated secretion from approximately $1.2 \mu M$ to $0.5 \mu M$. Chromaffin granules, the secretory granules, are known to shrink in hyperosmotic solution. The experiments indicate that shrunken chromaffin granules can undergo exocytosis and suggest that in intact cells elevated ionic strength rather than chromaffin granule shrinkage contributes to the inhibition of secretion by hyperosmotic solutions. The experiments place limits on the possible osmotic mechanisms that could be involved in exocytosis. Key Words: Osmolality -- Ionic strength-Catecholamine exocytosis-Adrenal chromaffin cells-Digitonin-Carbohydrates. Holz R. W. and Senter R. A. Effects of osmolality and ionic strength on secretion from adrenal chromaffin cells permeabilized with digitonin. J. Neurochem. 46, 1835-1842 (1986).
Although exocytosis has been clearly defined in many systems, the biochemical and physiological events underlying exocytosis are still poorly understood. Among the best defined exocytotic systems is the adrenal medulla. $\mathrm{Ca}^{2+}$ entry (Douglas and Poisner, 1961; Kilpatrick et al., 1982; Holz et al., 1982) and a rise in cytosolic $\mathrm{Ca}^{2}+$ (Knight and Kesteven, 1983) caused by cholinergic stimulation result in the exocytotic release of catecholamine and other soluble constituents of the secretory vesicle, the chromaffin granule.

There is evidence that osmotic forces could play a role in granule membrane fusion with the plasma membrane. Swelling of artificial lipid vesicles enhances vesicle-planar bilayer fusion (Cohen et al., 1982). In a previous study with chromaffin cells we found that secretion was inhibited by hyperosmotic solutions at a step after $\mathrm{Ca}^{2+}$ entry (Hampton and Holz, 1983). Raising the osmolality from $300 \mathrm{mOs}$ to $450-500 \mathrm{mOs}$ inhibited nicotinic agonist-induced catecholamine secretion approximately $50 \%$. The inhibition may have been caused by an inability of shrunken granules to undergo exocytosis. Hyperosmotic solutions also inhibit exocytosis in dispersed parathyroid cells (Brown et al., 1978), sea urchin eggs (Zimmerberg and Whitaker, 1985), and
Received August 26, 1985; accepted December 17, 1985.

Address correspondence to Dr. R. W. Holz at Department of Pharmacology, University of Michigan Medical School, M6322 Medical Science Bldg. 1, Ann Arbor, MI 48109, U.S.A.

Abbreviations used: KGEP, solution containing $139 \mathrm{mM}$ po- tassium glutamate, $20 \mathrm{~m} M$ PIPES (pH 6.6), $1 \mathrm{~m} M \mathrm{MgATP}$, and either $5 \mathrm{~m} M$ EGTA (without $\mathrm{Ca}^{2+}$ ) or $5 \mathrm{mM}$ EGTA and various amounts of $\mathrm{CaCl}_{2}$; PIPES, piperazine- $N, N^{\prime}$-bis(2-ethanesulfonic acid). 
toad urinary bladder (Kachadorian et al., 1981). Although the data are consistent with osmotic stress of the secretory granule playing a role in exocytosis, a number of other effects may be responsible for the inhibition of secretion. For example, inhibition of secretion could result from changes in the intracellular ionic strength, changes in the concentrations of various intracellular constituents, or changes in the spatial relationships between secretory granules and the plasma membrane.

To examine more directly the effects of hyperosmotic solutions on the capacity of chromaffin granules to undergo secretion, we utilized monolayer cultures of bovine adrenal chromaffin cells with plasma membranes rendered leaky with the detergent digitonin. Incubation for 5-15 min with 20 $\mu M$ digitonin renders the plasma membrane leaky to $\mathrm{Ca}^{2+}$, ATP, carbohydrates, and lactic dehydrogenase but causes little or no leakage of catecholamine from the intracellular chromaffin granules (Dunn and Holz, 1983; Wilson and Kirshner, 1983; Holz and Senter, 1985). Micromolar $\mathrm{Ca}^{2+}$ in the presence of ATP stimulates secretion from digitonin-treated cells by a process very similar, if not identical, to exocytosis. A large $\mathrm{H}^{+}$electrochemical gradient can be sustained across the membrane of chromaffin granules within digitonin-treated cells which indicates that the granule membrane retains its high electrical resistance (Holz and Senter, 1985). In addition, granules have an osmotic stability similar to that of granules within cells not treated with digitonin (Holz and Senter, 1985). Solutions made hyperosmotic with low-molecularweight salts or carbohydrates as large as the tetrasaccharide stachyose rapidly equilibrate across the leaky plasma membranes of digitonin-treated cells, causing little or no cell shrinkage and directly bathe apparently normal intracellular chromaffin granules (Holz and Senter, 1985).

In this study we examined the effects of increased osmolality and increased ionic strength on $\mathrm{Ca}^{2+}$-dependent secretion from digitonin-treated cells.

\section{MATERIALS AND METHODS}

Primary dissociated cells from bovine adrenal medulla were prepared and maintained as monolayer cultures in Eagle's minimal essential medium (GIBCO, Grand Island, NY, U.S.A.) containing $10 \%$ heat-inactivated fetal calf serum as previously described (Fenwick et al., 1978; Holz et al., 1982). The culture medium contained 100 $\mathrm{U} / \mathrm{ml}$ of penicillin, $100 \mu \mathrm{g} / \mathrm{ml}$ of streptomycin, $50 \mu \mathrm{g} / \mathrm{ml}$ of gentamycin, and $1.3 \mu \mathrm{g} / \mathrm{ml}$ of Fungizone (Squibb) to prevent bacterial and fungal contamination. The culture medium also contained $10 \mu M$ cytosine arabinoside to inhibit fibroblast growth. Cells were cultured as monolayers in wells (Costar, Cambridge, MA, U.S.A.) in 6.4-mm diameter plastic culture wells (Costar) at a density of 500,000 cells $/ \mathrm{cm}^{2}$. Experiments were performed 4-14 days after preparation. There were approximately
$40 \mathrm{nmol}$ of catecholamine/million cells. Immediately before an experiment, cells were incubated for $1 \mathrm{~h}$ with physiological salt solution containing $145 \mathrm{mM} \mathrm{NaCl}, 5.6$ $\mathrm{m} M \mathrm{KCl}, 2.2 \mathrm{~m} M \mathrm{CaCl}_{2}, 0.5 \mathrm{~m} M \mathrm{MgCl}_{2}, 5.6 \mathrm{~m} M$ glucose, $15 \mathrm{~m} M N$-2-hydroxyethylpiperazine- $N^{\prime}$-2-ethanesulfonic acid (HEPES) (pH 7.4), and $0.5 \mathrm{~m} M$ sodium ascorbate. An experiment was initiated by replacing the medium with new solution. All experiments were performed at $25^{\circ} \mathrm{C}$.

Potassium glutamate solution (KGEP) used in the digitonin experiments contained $139 \mathrm{~m} M$ potassium glutamate, $20 \mathrm{~m} M$ piperazine- $N, N^{\prime}$-bis(ethanesulfonic acid) (PIPES; pH 6.6), $1 \mathrm{~m} M \mathrm{MgATP}$, and either $5 \mathrm{~m} M$ EGTA (without $\mathrm{Ca}^{2+}$ ) or $5 \mathrm{mM}$ EGTA and various amounts of $\mathrm{CaCl}_{2}$. Calcium concentrations in calcium-EGTA buffers were calculated according to Portzehl et al. (1964) and Fabiato and Fabiato (1979) using a $\mathrm{Ca}^{2+}$ association constant of $10^{5.89}$ at $\mathrm{pH}$ 6.6. The calcium-EGTA equilibrium was little altered by the concentrations of $\mathbf{M g}^{2+}$ and ATP, or glutamate that was present. Small decreases in the $\mathrm{Ca}^{2+}$-EGTA association constant caused by increased ionic strength in some experiments were estimated according to Fabiato and Fabiato (1979) and resulted in a $<30 \%$ increase in the calculated free $\mathrm{Ca}^{2+}$ concentration. Decreased ionic strength caused by isoosmotic replacement of potassium glutamate by sucrose resulted in $30 \%$ decrease in the calculated free $\mathrm{Ca}^{2+}$ and was similarly taken into account in the figures. Digitonin, $20 \mu M$, was routinely used to increase the permeability of the plasma membrane.

Catecholamine release was monitored by determining the percentage of $\left[{ }^{3} \mathrm{H}\right]$ norepinephrine released into the medium from cells that had been previously incubated in $\left[{ }^{3} \mathrm{H}\right]$ norepinephrine-containing solution according to Kilpatrick et al. (1980). The cellular radioactivity was determined after disrupting the cells in $1 \%$ Triton X-100.

Sucrose, raffinose, stachyose, and maltodextrin were deionized with Amberlite MB-3 (Mallinckrodt, Paris, KY, U.S.A.). Five grams of carbohydrate and $5 \mathrm{ml}$ of moist resin were continuously agitated in $50 \mathrm{ml}$ deionized water. After $1 \mathrm{~h}$ at $4^{\circ} \mathrm{C}$ the resin was removed and washed with $50 \mathrm{ml}$ deionized water. The wash and the original deionized solution were combined and lyophilized for 48 $\mathrm{h}$. The spectrum of polysaccharides in the maltodextrin fraction was determined using gel chromatography (BioGel P-4, 200-400 mesh, $0.9 \mathrm{~cm} \times 280 \mathrm{~cm}$ column) with glucose, sucrose, raffinose, and stachyose as standards. The average size, a tetrasaccharide, agreed with the estimate based on osmolality. The free $\mathrm{Ca}^{2+}$ concentration was measured with a $\mathrm{Ca}^{2+}$-selective electrode made from the neutral carrier ETH 1001 (Affolter and Sigel, 1979). The addition of $500 \mathrm{~m} M$ deionized sucrose, raffinose, stachyose, or maltodextrin to potassium glutamate solution containing $10 \mu M$ free $\mathrm{Ca}^{2+}$ buffered with $5 \mathrm{mM}$ EGTA (total osmolality $1,000 \mathrm{mOs}$ ) did not alter the free $\mathrm{Ca}^{2+}$ concentration.

Osmolalities were measured with a vapor pressure osmometer (Wescor, Logan, UT, U.S.A.). Radioactivity was determined by liquid scintillation spectroscopy with a counting efficiency for tritium of $40 \%$.

The low-molecular-weight fraction of maltodextrin was obtained from V-Labs (Covington, LA, U.S.A.). Components of the $\mathrm{Ca}^{2+}$-selective electrodes-o-nitrophenyl- $n$ octyl ether, ETH 1001, and potassium tetra-( $p$-chlorophenyl)borate - were obtained from Fluka Chemical 
(Hauppauge, NY, U.S.A.). Bio-Gel P-4, 200-400 mesh, was obtained from Bio-Rad Laboratories (Richmond, CA, U.S.A. $1-\left[7-{ }^{3} \mathrm{H}\right]$ Norepinephrine $(21.4 \mathrm{Ci} / \mathrm{mmol})$ was obtained from New England Nuclear (Boston, MA, U.S.A.). Data were expressed as means \pm SEM. When the difference between two groups was determined, the $\mathrm{SEM}$ was calculated as $\left(\mathrm{SE}_{1}^{2}+\mathrm{SE}_{2}^{2}\right)^{\mathrm{r}_{2}}$ where $\mathrm{SE}_{1}$ and $\mathrm{SE}_{2}$ are the standard errors of the mean for each group. SEM bars smaller than symbols or lines were omitted from figures. Differences between means of groups were tested for significance with Student's $t$ test.

\section{RESULTS}

Effects of solutions made hyperosmotic with carbohydrates on secretion from digitonin-treated cells

Increasing the osmolality of KGEP solution with sucrose resulted in inhibition of $\mathrm{Ca}^{2+}$-dependent secretion, with half-maximal inhibition occurring at approximately 1,200 mOs (Fig. 1). In seven experiments in which the osmolality of a solution containing $139 \mathrm{~m} M$ potassium glutamate was increased from $310 \mathrm{mOs}$ to $1,000 \mathrm{mOs}$ with sucrose, $\mathrm{Ca}^{2+}$-dependent secretion was inhibited between 0 and $30 \%$ with an average inhibition of $13 \%$.

The effects of various concentrations of several other carbohydrates were also investigated (Fig. 1). Although sucrose equilibrates across the plasma membrane of digitonin-treated cells within $2 \mathrm{~min}$, equilibration of the larger carbohydrates stachyose and maltodextrin may require 6-10 $\mathrm{min}$ (Holz and

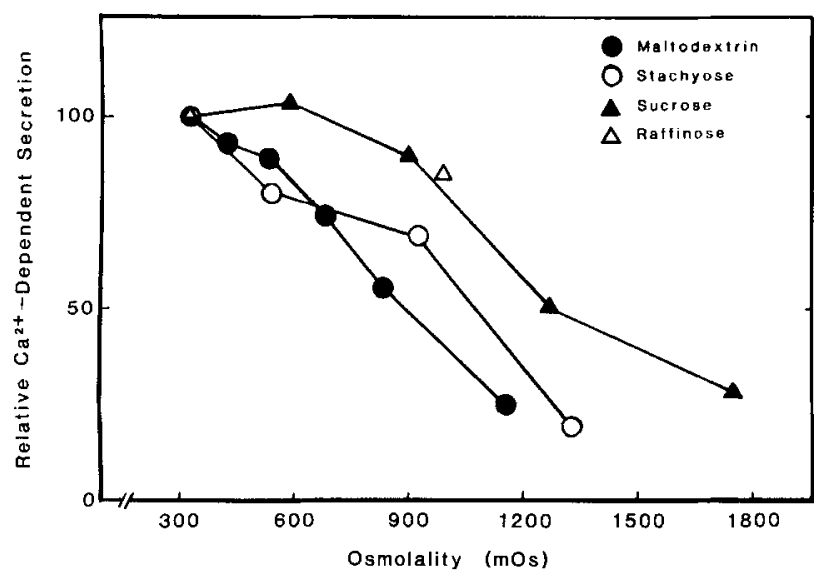

FIG. 1. Effects of hyperosmotic solutions on $\mathrm{Ca}^{2+}$-dependent secretion from digitonin-treated chromaffin cells. Chromaffin cells were incubated in $\mathrm{Ca}^{2+}$-free potassium glutamate solution containing $1 \mathrm{mM} \mathrm{MgATP}$ and $20 \mu \mathrm{M}$ digitonin. After 5 min the solution was replaced with $\mathrm{Ca}^{2+}$-free potassium glutamate without digitonin containing $1 \mathrm{mM}$ MgATP and various concentrations of maltodextrin (average size, tetrasaccharide), stachyose, raffinose, or sucrose. After $8 \mathrm{~min}$, the solutions were replaced with the same solutions $\pm 10 \mu \mathrm{M} \mathrm{Ca}^{2+}$. $\mathrm{Ca}^{2+}$-dependent secretion was determined after $15 \mathrm{~min}$. There were four samples/group. Standard errors of the mean were generally $<10 \%$ of secretion and error bars were omitted.
Senter, 1985). The experiments shown in Fig. 1 were conducted with an incubation in $\mathrm{Ca}^{2+}$-free, hyperosmotic solution for $8 \mathrm{~min}$, which is enough time to allow equilibration of stachyose and maltodextrin across the leaky plasma membrane (Holz and Senter, 1985). Secretion was then stimulated by $\mathrm{Ca}^{2+}$-containing medium of the same carbohydrate composition. Increasing the osmolality with the trisaccharide raffinose, with the tetrasaccharide stachyose, or with a low-molecular-weight maltodextrin fraction (average size a tetrasaccharide) inhibited secretion (Fig. 1). Stachyose and maltodextrin caused one-half maximal inhibition of secretion between 900 and 1,000 mOs. It should be noted that the concentrations of sucrose, stachyose, and maltodextrin required to half-maximally inhibit secretion were all approximately $0.3 \mathrm{~g} / \mathrm{ml}$.

The effects of solutions of different osmolalities in which sucrose was the main osmoticant (no potassium glutamate) were also investigated (Fig. 2). Hypoosmotic solutions inhibited secretion. Hyperosmotic solutions had little effect until osmolalities of $>1,000 \mathrm{mOs}$ were attained. Less than $50 \%$ inhibition occurred at 1,400 mOs osmolality.

Effect of preincubation in $\mathrm{Ca}^{2+}$-containing hyperosmotic solution on subsequent secretion

Zimmerberg and Whitaker (1985) found, using

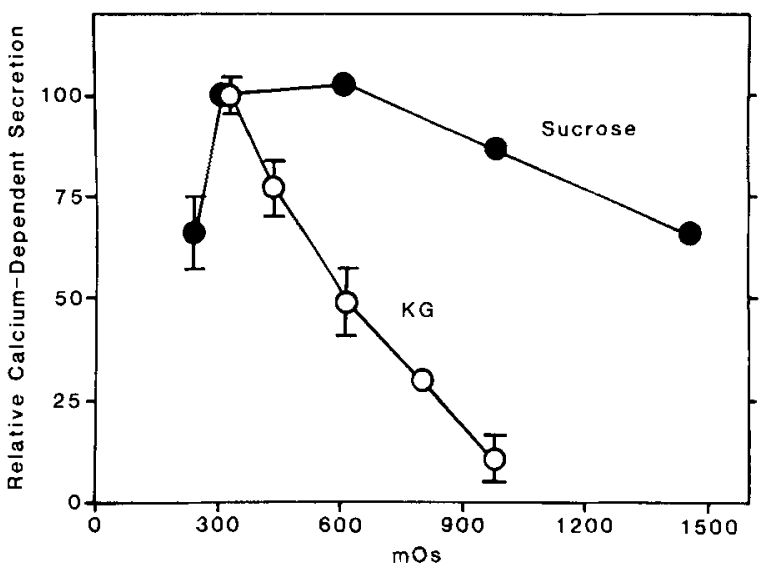

FIG. 2. Effects of various concentrations of potassium glutamate or sucrose on secretion. Cells were permeabilized with $139 \mathrm{mM}$ potassium glutamate, $20 \mathrm{mM}$ PIPES ( $\mathrm{pH} 6.6$ ), $5 \mathrm{mM}$ EGTA, $1 \mathrm{mM} \mathrm{MgATP}$, and $20 \mu \mathrm{M}$ digitonin for $5 \mathrm{~min}$. In the potassium glutamate experiment (KG) the digitonin-containing solution was replaced with solution containing 20 $\mathrm{m} M$ PIPES ( $\mathrm{pH}$ 6.6), $5 \mathrm{mM}$ EGTA, $1 \mathrm{mM} \mathrm{MgATP}$, and various concentrations of potassium glutamate. After $8 \mathrm{~min}$ the solution was replaced with a solution of the same composition \pm $10 \mu M$ free $\mathrm{Ca}^{2+} . \mathrm{Ca}^{2+}$-dependent secretion was determined after $15 \mathrm{~min}$. In the sucrose experiment, the digitonin-containing solution was replaced with $20 \mathrm{mM}$ PIPES (pH 6.6), 1 $\mathrm{mMMg} \mathrm{Mg}^{2+}, 1 \mathrm{mM}$ ATP $\pm 10 \mu \mathrm{MCa}^{2+}$, and various concentrations of sucrose. $\mathrm{Ca}^{2+}$-dependent secretion was determined after $15 \mathrm{~min}$. Secretion at $320 \mathrm{mOs}$ was in $5.3 \%$ in the potassium glutamate experiment and $9.1 \%$ in the sucrose experiment. The experiments were performed on different preparations of cells. There were four samples/group. 
disrupted sea urchin eggs in which the secretory apparatus was exposed to direct manipulation, that solutions made hyperosmotic with stachyose inhibited $\mathrm{Ca}^{2+}$-dependent exocytosis. Furthermore, if disrupted eggs were exposed to $\mathrm{Ca}^{2+}$-containing solutions made hyperosmotic with stachyose, exocytosis occurred on introduction of normal osmolality in $\mathrm{Ca}^{2+}$-free medium. The results were consistent with separate $\mathrm{Ca}^{2+}$-dependent and osmotic processes in exocytosis in sea urchin eggs. We performed analogous experiments in digitonin-treated chromaffin cells (Table 1). Digitonin-permeabilized cells were incubated in solutions made hyperosmotic $(1,300 \mathrm{mOs})$ with stachyose in the presence or absence of $10 \mu M \mathrm{Ca}^{2+}$. $\mathrm{Ca}^{2+}$-dependent secretion was completely inhibited in this solution. When the solution was subsequently replaced with isoosmotic solution ( $300 \mathrm{mOs})$ in the absence of $\mathrm{Ca}^{2+}$, the amount of $\left[{ }^{3} \mathrm{H}\right]$ norepinephrine released into the $\mathrm{Ca}^{2+}$-free medium was the same for cells exposed to hyperosmotic solution in the presence (group 4) or absence (group 3) of $\mathrm{Ca}^{2+}$. Similarly, the amounts of $\left[{ }^{3} \mathrm{H}\right]$ norepinephrine released into isoosmotic medium containing $10 \mu M \mathrm{Ca}^{2+}$ by cells preincubated in hyperosmotic solution in the presence (group 6) or absence (group 5) of $\mathrm{Ca}^{2+}$ were similar. Thus, $\mathrm{Ca}^{2+}$ pretreatment of permeabilized cells in the presence of stachyose to inhibit secretion did not predispose the cells to secrete when the osmolality was lowered. The small amount of $\mathrm{Ca}^{2+}$-independent $\left[{ }^{3} \mathrm{H}\right]$ norepinephrine release that occurred when the osmolality was reduced from $1,300 \mathrm{mOs}$ to $300 \mathrm{mOs}$ (compare groups 3 and 4 with groups 1 and 2) was also observed when the osmoticant was sucrose (data not shown). Because the small amount of release was independent of the

TABLE 1. Effect of preincubation in $\mathrm{Ca}^{2+}$-containing hyperosmotic solution on subsequent secretion from permeabilized cells

\begin{tabular}{llc}
\hline \multicolumn{1}{c}{ Preincubation } & \multicolumn{1}{c}{ Incubation } & $\begin{array}{c}\text { Percent of total } \\
{\left[{ }^{3} \mathrm{H} \text { ]norepinephrine }\right.} \\
\text { in medium }\end{array}$ \\
\hline 1. $300 \mathrm{mOs}, 0 \mathrm{Ca}^{2+}$ & $300 \mathrm{mOs}, 0 \mathrm{Ca}^{2+}$ & $2.7 \pm 0.2$ \\
2. $\quad 300 \mathrm{mOs}, 0 \mathrm{Ca}^{2+}$ & $300 \mathrm{mOs}, 10 \mu M \mathrm{Ca}^{2+}$ & $15.7 \pm 0.2^{\circ}$ \\
3. $1,300 \mathrm{mOs}, 0 \mathrm{Ca}^{2+}$ & $300 \mathrm{mOs}, 0 \mathrm{Ca}^{2+}$ & $8.5 \pm 0.2$ \\
4. $1,300 \mathrm{mOs}, 10 \mu M \mathrm{Ca}^{3+}$ & $300 \mathrm{mOs}, 0 \mathrm{Ca}^{2+}$ & $8.7 \pm 0.3$ \\
5. $1,300 \mathrm{mOs}, 0 \mathrm{Ca}^{2+}$ & $300 \mathrm{mOs}, 10 \mu M \mathrm{Ca}^{2+}$ & $16.0 \pm 1.3^{\prime \prime}$ \\
6. $1,300 \mathrm{mOs}, 10 \mu M \mathrm{Ca}^{3+}$ & $300 \mathrm{mOs}, 10 \mu M \mathrm{Ca}^{2+}$ & $16.6 \pm 0.1^{\circ}$ \\
\hline
\end{tabular}

Cells were permeabilized by a 5 -min incubation in $\mathrm{Ca}^{2+}$-free $\mathrm{KGEP}$ (300 mOs) containing $2 \mathrm{mM} \mathrm{MgCl}, 1 \mathrm{~m} M$ ATP, and $20 \mu M$ digitonin. Cells were then preincubated for $8 \mathrm{~min}$ in KGEP with $2 \mathrm{~m} M \mathrm{MgCl}_{2}, 1 \mathrm{mM}$ ATP, with or without stachyose to raise the osmolality to $1,300 \mathrm{mOs}$. Some solutions also contained $10 \mu M$ free $\mathrm{Ca}^{2}$. Cells were then incubated in KGEP $(300 \mathrm{mOs})$ with $2 \mathrm{mM} \mathrm{MgCl}, 1 \mathrm{~m} M$ ATP $\pm 10 \mu M$ free $\mathrm{Ca}^{2+}$ and secretion measured after $15 \mathrm{~min}$. There were four wells/group. $\mathrm{Ca}^{2+}$-dependent secretion was completely inhibited at 1,300 $\mathrm{mOs}$ during the preincubation.

" $\mathrm{p}<0.001$ versus group 1

${ }^{b} \mathbf{p}<0.001$ versus group 3

$\mathrm{p}<0.001$ versus group 4 size of the carbohydrate, it probably did not result from carbohydrate transport into the granules and increased osmotic stress when granules were exposed to $300 \mathrm{mOs}$ solution.

\section{Effects of elevated ionic strength on secretion}

Solutions with elevated salts inhibited $\mathrm{Ca}^{2+}$-dependent secretion. For example, when the potassium glutamate concentration was raised from 139 $\mathrm{m} M$ to $350 \mathrm{~m} M$, which raised the osmolality from $300 \mathrm{mOs}$ to $710 \mathrm{mOs}$, secretion was inhibited approximately $50 \%$ (Fig. 3). Increasing the tonicity with potassium glutamate (Figs. 2 and 3 ) or sodium isethionate (Fig. 4) resulted in inhibition of $\mathrm{Ca}^{2+}$ dependent secretion, with half-maximal inhibition of secretion occurring with both salts at approximately $600-700 \mathrm{mOs}$ or $300-350 \mathrm{~m} M$ salt.

The inhibition induced by elevated potassium glutamate solutions occurred when secretion was examined in solutions of constant osmolality (Fig. $5)$. When the osmolality was maintained at 1,000 mOs by the addition of sucrose, inhibition was onehalf maximal at $250 \mathrm{~m} M-350 \mathrm{~m} M$ potassium glutamate. Thus, inhibition of secretion occurred at similar ionic strengths under conditions of constant or varying osmolality.

To determine whether the inhibition by elevated salts could be caused by decreased sensitivity to $\mathrm{Ca}^{2+}$, the effects of various $\mathrm{Ca}^{2+}$ concentrations on

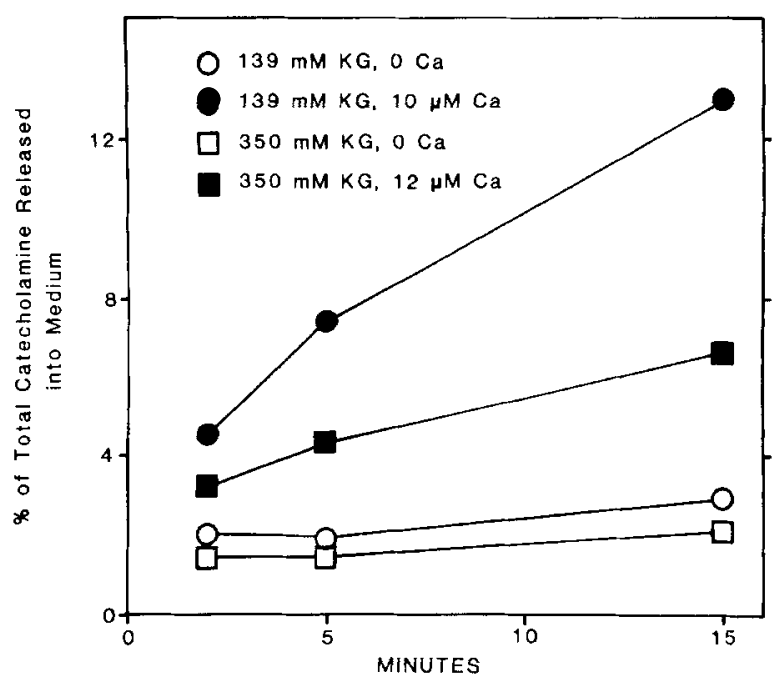

FIG. 3. Effects of elevated potassium glutamate on the time course of secretion. Chromaffin cells were incubated for 5 $\mathrm{min}$ in $139 \mathrm{mM}$ potassium glutamate, $20 \mathrm{mM}$ PIPES (pH 6.6), $5 \mathrm{mM}$ EGTA, $2 \mathrm{mM} \mathrm{Mg}{ }^{2}, 1 \mathrm{mM}$ ATP, and $20 \mu M$ digitonin. Cells were then incubated in digitonin-free solution containing either $139 \mathrm{mM}$ or $350 \mathrm{mM}$ potassium glutamate (KG) with $20 \mathrm{~m} M$ PIPES (pH 6.6), $5 \mathrm{mM}$ EGTA, $2 \mathrm{mM} \mathrm{Mg}{ }^{2}$ ।, $1 \mathrm{mM}$ ATP in the absence or presence of $10-12 \mu M$ free $\mathrm{Ca}^{2+}$. Secretion was measured at the indicated times. The osmolalities of the $139 \mathrm{mM}$ and the $350 \mathrm{mM}$ potassium glutamate solutions were $300 \mathrm{mOs}$ and $710 \mathrm{mOs}$, respectively. There were four wells/group. 


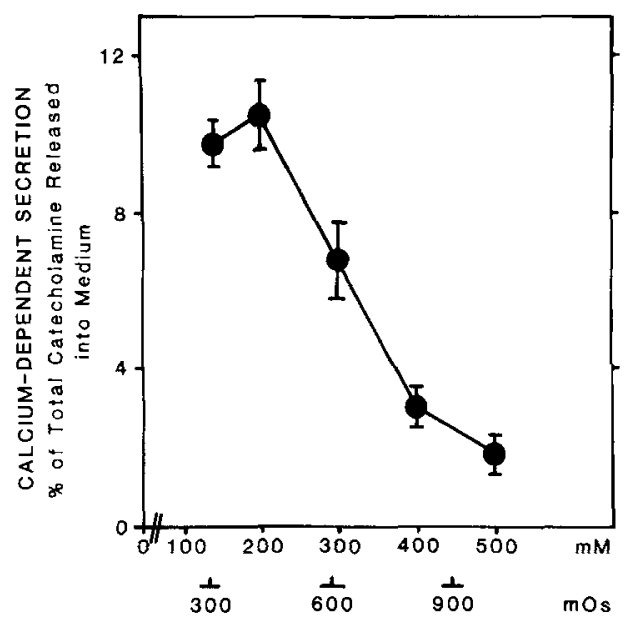

FIG. 4. Effects of various concentrations of sodium isethionate on secretion. Chromaffin cells were incubated for $5 \mathrm{~min}$ in $139 \mathrm{mM}$ potassium glutamate, $20 \mathrm{mM}$ PIPES ( $\mathrm{pH} 6.6), 5$ $\mathrm{mM}$ EGTA, $2 \mathrm{mM} \mathrm{MgCl} 2,1 \mathrm{mM}$ ATP, and $20 \mu M$ digitonin. The solution was replaced with $20 \mathrm{mM}$ PIPES, $5 \mathrm{mM}$ EGTA, $2 \mathrm{mM}$ $\mathrm{MgCl}_{2}, 1 \mathrm{mM} \mathrm{ATP}$, and various concentrations of sodium isethionate with and without $10-12 \mu M$ free $\mathrm{Ca}^{2+} . \mathrm{Ca}^{2+}$-dependent secretion was determined after $15 \mathrm{~min}$. There were four wells/group.

secretion in isotonic and hypertonic solutions of potassium glutamate were investigated. The relative inhibition by elevated potassium glutamate solution was similar at all $\mathrm{Ca}^{2+}$ concentrations (Fig. $6 \mathrm{~A}$ ). It is thus unlikely that the inhibition of secretion was caused by altered $\mathrm{Ca}^{2+}$ sensitivity of processes involved in secretion. Interestingly, lowering the ionic strength by substituting isoosmotic sucrose for potassium glutamate caused an increase in $\mathrm{Ca}^{2+}$ sensitivity (Fig. 6B). The concentration necessary to stimulate secretion half-maximally was reduced from $1.2 \mu M$ in potassium glutamate to $0.5 \mu M$ in sucrose solution. ${ }^{1}$

\section{DISCUSSION}

Shrunken chromaffin granules undergo secretion

In a previous study with intact chromaffin cells, we found that hyperosmotic solutions inhibited nicotinic agonist- and elevated $\mathrm{K}^{+}$-induced secretion at a step after $\mathrm{Ca}^{2+}$ entry (Hampton and Holz, 1983). Secretion stimulated by veratridine and acetylcholine from suspended chromaffin cells was also inhibited by elevated osmolality (Pollard et al., 1984). The data were consistent with osmotic stress of the chromaffin granule being important in granule membrane-plasma membrane fusion. However, hyperosmotic solutions caused not only chromaffin granule shrinkage, but also cell shrinkage,

${ }^{1}$ Half-maximal secretion in isoosmotic solutions of potassium glutamate, potassium propionate, and sodium isethionate all occurred at 1.2-1.4 $\mu M \mathrm{Ca}^{2+}$.

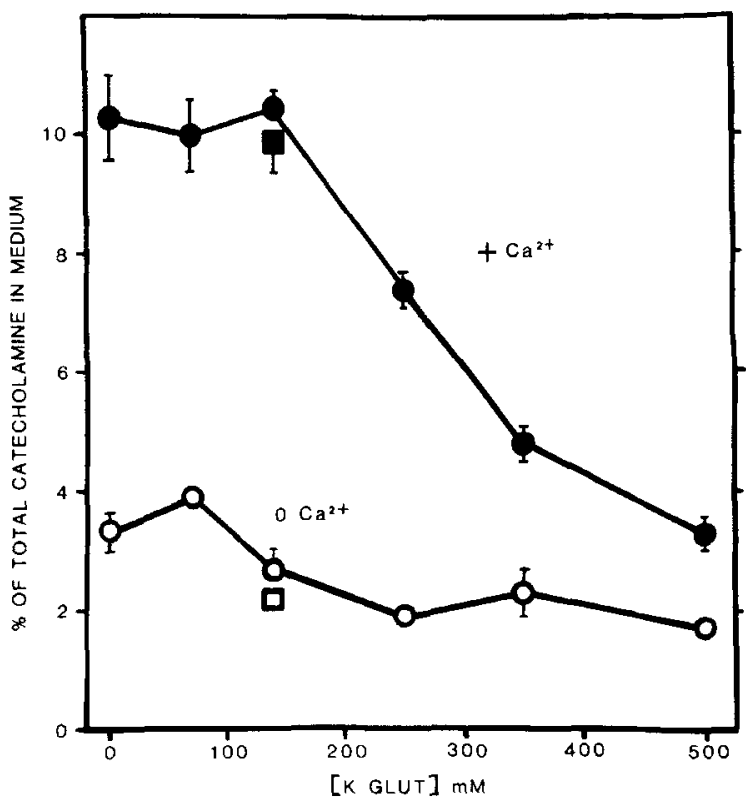

FIG. 5. Effect of increasing potassium glutamate concentration at constant osmolality. Cells were permeabilized in 139 $\mathrm{m} M$ potassium glutamate ( $\mathrm{K}$ Glut) solution, $20 \mathrm{mM}$ PIPES, 5 $\mathrm{mM}$ EGTA, $2 \mathrm{mM} \mathrm{Mg}^{2+}, 1 \mathrm{mM}$ ATP, and $20 \mu M$ digitonin (pH 6.6). After $6 \mathrm{~min}$ the solution was replaced with solutions containing $20 \mathrm{mM}$ PIPES, $5 \mathrm{mM}$ EGTA, $2 \mathrm{mM} \mathrm{Mg}{ }^{2+}, 1 \mathrm{mM}$ ATP $\pm 10 \mu M$ free $\mathrm{Ca}^{2+}$, and various concentrations of potassium glutamate and sucrose to maintain 1,000 mos $(O$, -). In two groups solution was changed to 320 mos potassium glutamate solution without sucrose $(\square, \square)$. $\mathrm{Ca}^{2+}$-dependent secretion was determined after $15 \mathrm{~min}$.

increased intracellular ionic strength, and changes in spatial relationships between granules and plasma membrane. Experiments with digitonintreated chromaffin cells minimized many of these complications. The osmoticants in the present study (potassium glutamate, sodium isethionate, and a variety of carbohydrates) rapidly equilibrated across the plasma membrane and probably directly bathed the intracellular organelles ( $\mathrm{Holz}$ and Senter, 1985). Secretion from digitonin-treated cells was much less sensitive to solutions made hyperosmotic with carbohydrate than secretion from intact cells. For example, half-maximal inhibition of secretion by the disaccharide sucrose when added to isoosmotic salt solution occurred at 1,200 mOs in digitonin-treated cells and at 450-500 mOs in intact cells. The larger carbohydrate stachyose (a tetrasaccharide) and a low-molecular-weight fraction of maltodextrin (average polysaccharide size was a tetrasaccharide) caused one-half maximal inhibition at $900-1,000 \mathrm{mOs}$ in digitonin-treated cells.

Chromaffin granules in vitro lyse virtually completely when the osmolality is lowered from 300 mOs to $200 \mathrm{mOs}$ (Perlman, 1976; Sudhof, 1982; Hampton and Holz, 1983) and are stable in isoosmotic sucrose solution ( $t_{1 / 2}$ for release of catecholamine at $37^{\circ} \mathrm{C}$ is $2 \mathrm{~h}$ ) (Lishajko, 1970; Sudhof, 1982). Chromaffin granules shrink in hyperosmotic 

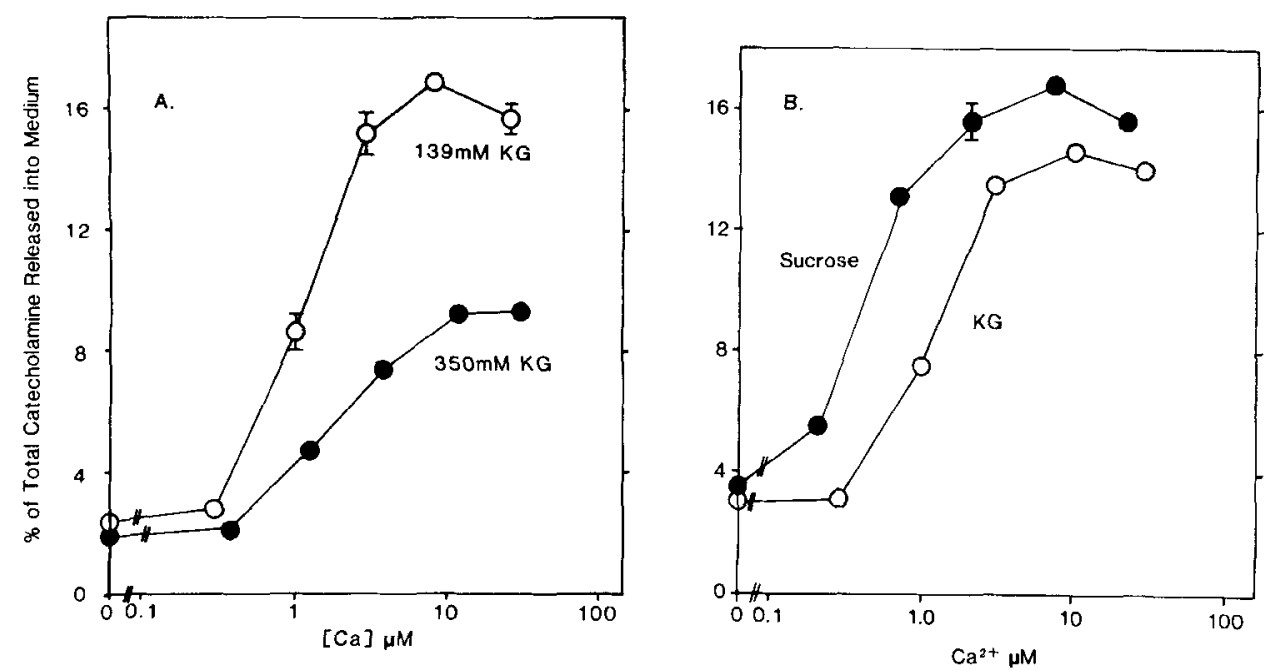

FIG. 6. Effects of various $\mathrm{Ca}^{2+}$ concentrations on secretion in different ionic strength solutions. A: Secretion in normal and elevated potassium glutamate $(\mathrm{KG})$ solutions. Chromaffin cells were incubated for $5 \mathrm{~min}$ in $139 \mathrm{mM}$ potassium glutamate, $20 \mathrm{mM}$ PIPES, $10 \mathrm{mM}$ EGTA, $2 \mathrm{mM} \mathrm{MgCl}$, $1 \mathrm{mMATP}$, and $20 \mu \mathrm{M}$ digitonin. The solution was replaced with solution containing either $139 \mathrm{mM}$ or $350 \mathrm{mM}$ potassium glutamate and $20 \mathrm{mM}$ PIPES, $10 \mathrm{mM}$ EGTA, $2 \mathrm{mM} \mathrm{MgCl}$, $1 \mathrm{mM}$ ATP, and varying amounts of free $\mathrm{Ca}^{2+}$. Secretion was measured after $15 \mathrm{~min}$. There were four wells/group. B: Secretion in isoosmotic sucrose and potassium glutamate solutions. Chromaffin cells were incubated for $5 \mathrm{~min}$ in $139 \mathrm{mM}$ potassium glutamate, $20 \mathrm{mM}$ PIPES (pH 6.60), $5 \mathrm{mM}$ EGTA, $2 \mathrm{mM} \mathrm{MgCl} 2,1 \mathrm{mMATP}$, and $20 \mu M$ digitonin. The solution was replaced with solution containing $20 \mathrm{mM}$ PIPES (pH 6.60) $5 \mathrm{mM}$ EGTA, $2 \mathrm{mM} \mathrm{MgCl}$, $1 \mathrm{mM}$ ATP, and various amounts of $\mathrm{Ca}^{2-}$ and $139 \mathrm{mM}$ potassium glutamate or $250 \mathrm{mM}$ sucrose. The osmolality of the solutions was 300-320 mOs. Secretion was measured after $15 \mathrm{~min}$. There were four wells/group.

sucrose solutions and are ideal osmometers in 300 mOs-1,000 mOs sucrose solutions (Sudhof, 1982). Thus, the chromaffin granule membrane is relatively impermeant to sucrose. Granules within digitonin-treated cells are osmotically more stable than granules in vitro and have an osmotic stability similar to that of granules in intact cells (Holz and Senter, 1985). Thus, it is highly likely that chromaffin granules in digitonin-treated cells were shrunken in hyperosmotic solutions that did not significantly inhibit secretion.

The high-osmolality, carbohydrate-containing solutions that did inhibit secretion from digitonintreated cells contained large amounts by weight of carbohydrate (approximately $0.3 \mathrm{~g} / \mathrm{ml}$ for half-maximal inhibition for all carbohydrates investigated). Although it is possible that the inhibition of secretion resulted from the elevated osmolality, it is also possible that the inhibitory effects of these solutions resulted from an effect of the carbohydrates on secretion that was independent of their molecular weights.

\section{Effects of increased ionic strength on secretion}

Increased concentrations of potassium glutamate or sodium isethionate inhibited secretion, with halfmaximal secretion occurring when the salt was increased from $139 \mathrm{~m} M$ to approximately $350 \mathrm{~m} M$. The effects of increased salt concentration also occurred when the osmolality was kept constant with sucrose. Thus, the inhibition of secretion probably occurred because of increased intracellular ionic strength rather than increased osmolality.
The inhibition of secretion by elevated ionic strength did not result from decreased sensitivity of the secretory apparatus to $\mathrm{Ca}^{2+}$. The relative inhibition of secretion caused by isotonic and elevated potassium glutamate was similar between 0.30 and $30 \mu M \mathrm{Ca}^{2+}$, with one-half maximal secretion occurring at approximately $1 \mu M$. It had been previously observed that $20 \mathrm{mM} \mathrm{Mg}^{2+}$ profoundly inhibited secretion from digitonin-treated cells (Wilson and Kirshner, 1983; Frye and Holz, 1985). It is possible that the same step that is inhibited by elevated ionic strength is also inhibited by elevated $\mathrm{Mg}^{2+}$.

\section{Relationship of the findings to exocytosis from intact cells}

Ionic strength is likely to increase in intact cells shrunken with ionic or nonionic osmoticants. The present experiments with digitonin-treated chromaffin cells suggest that in intact chromaffin cells the increased intracellular ionic strength but not osmolality is responsible for the inhibition of exocytosis by hyperosmotic solutions. Approximately doubling the ionic strength in digitonin-treated cells inhibits catecholamine secretion by $50 \%$. If the ionic strength doubles when the water space in the intact cells is halved, then a doubling of the osmolality from 300 to $600 \mathrm{mOs}$ should cause an approximately $50 \%$ inhibition of secretion. Nicotinic agonist- and depolarization-induced secretion were inhibited $80-90 \%$ by this increase in osmolality (Hampton and Holz, 1983; Pollard et al., 1984). It is therefore possible that factors in addition to in- 
creased ionic strength (but probably not including osmotic effects on the granules) may also contribute to the inhibition of secretion from intact cells by solutions of 300-600 mOs.

In a recent study with disrupted sea urchin eggs (Zimmerberg and Whitaker, 1985) prior treatment with $\mathrm{Ca}^{2+}$ at high osmolality caused exocytosis when the eggs were restored to normal osmolality. In analogous experiments in the present study, prior treatment of permeabilized chromaffin cells with $\mathrm{Ca}^{2+}$ in hyperosmotic solution in which secretion was inhibited did not result in enhanced secretion when cells were restored to normal osmolality. The data do not provide evidence for distinct $\mathrm{Ca}^{2+}$ dependent and osmotic processes in secretion from chromaffin cells.

The present experiments place limits on the possible osmotic mechanisms involved in secretion. If the inhibition of secretion from digitonin-treated cells by large amounts of carbohydrates is caused by osmotic effects, then a mechanism must exist to increase the osmotic equivalents within chromaffin granules sufficiently to cause water influx and granule lysis in solutions of $1,000 \mathrm{mOs}$ or greater. Intracellular chromaffin granules are stable at 300 mOs (physiological osmolality). Because inhibition of the lytic effects of a hypothetical increase in intragranular solutes requires solutions of approximately $1,000 \mathrm{mOs}$, there would have to be at least a tripling of osmotic equivalents in granules undergoing exocytosis. In addition, lysis of granules within cells probably requires an approximate doubling of the osmotically active water space (Hampton and Holz, 1983; Holz and Senter, 1985), which would necessitate a sixfold increase in osmotic equivalents within intracellular granules undergoing exocytosis. It is unlikely that decreased solute interactions within chromaffin granules could account for the necessary increase in osmotic equivalents. The granule interior is an extremely nonideal solution because of interactions between the major osmoticants, epinephrine and ATP (Kopell and Westhead, 1982; Sen and Sharp, 1982). The solute interactions are relatively insensitive to changes in $\mathrm{pH}$, divalent ions, $\mathrm{NaCl}$, or $\mathrm{KCl}$. Substitution of $\mathrm{Na}^{+}$for catecholamine also results in a very nonideal solution (Kopell and Westhead, 1982; Sen and Sharp, 1982). Physiologically relevant ways of significantly decreasing the nonideal behavior are unknown. Activation of a pump in the granule membrane that transports solutes into the granule is also an unlikely mechanism to increase sufficiently the number of osmotically active solutes. $\mathrm{H}^{+}, \mathrm{Cl}^{-}$cotransport coupled to the $\mathrm{H}^{+}$ translocating ATPase of the chromaffin granule membrane cannot account for the necessary influx (Baker and Knight, 1984; Holz and Senter, 1985). There is no known active transport system in the granule membrane that can cause the necessary large and rapid influx of solutes.

One mechanism that could cause the necessary increase in osmotic equivalents is an increase in permeability of the granule membrane to extracellular components at the site of fusion with the plasma membrane or to cytosolic components at nonfusion sites without a permeability increase to intragranular contents. Because granules would never reach osmotic equilibrium, they would lyse.? Inhibition by large amounts of carbohydrate of the rate and maximum degree of secretion from digitonin-permeabilized cells would occur if the extragranular osmoticant equilibrates slowly relative to the lifetime of the permeability change. At present, there is no direct evidence for such a permeability change.

Comparison with results from suspended chromaffin cells with plasma membranes rendered leaky by intense electric fields

$\mathrm{Ca}^{2+}$-dependent secretion from suspended chromaffin cells rendered leaky by intense electric fields was inhibited approximately $50 \%$ by $700 \mathrm{mOs}$ sucrose solution (Knight and Baker, 1982), in contrast to the absence of inhibition under similar conditions with digitonin-treated cells (the present study). The different effects of hyperosmotic sucrose solution probably resulted from differences in the permeability characteristics of the two preparations. Dielectric breakdown caused less drastic permeability changes of the plasma membrane than digitonin treatment. For example, the dielectric breakdown method causes $<10 \%$ of the lactate dehydrogenase to leave chromaffin cells in $20 \mathrm{~min}$ (Knight and Baker, 1982). In contrast, digitonin treatment causes over $50 \%$ of the lactate dehydrogenase to leave cells within a similar time. Similarly, 3-O-methylglucose exits from cells exposed to intense electric fields with a half-time of $20 \mathrm{~min}$ (Knight and Baker, 1982). Sucrose equilibrates across the plasma membrane of digitonin-treated cells within $2 \mathrm{~min}$ (Holz and Senter, 1985). It is likely that sucrose was not equilibrated across the plasma membrane during the experiment with cells rendered leaky with electric field. Cell shrinkage and a resulting increase in ionic strength may account for the greater sensitivity of these cells compared with digitonin-treated cells to increased osmolality.

Acknowledgment: We thank Drs. Alan Finkelstein, Joshua Zimmerberg, Frederic Cohen, and Michael Whitaker for helpful discussions concerning this work. The work was supported by U.S. Public Health Service Grant RO-1 AM27959, and NSF Grant BNS 8211493. R.W.H. is an Established Investigator of the American Heart Association.

\footnotetext{
${ }^{2}$ See Cohen et al. (1982) for an example with artificial vesicles.
} 


\section{REFERENCES}

Affolter H. and Sigel E. (1979) A simple system for the measurement of ion activities with solvent polymeric membrane electrodes. Anal. Biochem. 97, 315-319.

Baker P. F. and Knight D. E. (1984). Chemosmotic hypothesis of exocytosis: a critique. Biosci. Rep. 4, 285-298.

Brown W. M., Pazoles C. J., Creutz C. E., Aurbach G. D., and Pollard H. B. (1978) Role of anions in parathyroid release from dispersed bovine parathyroid cells. Proc. Natl. Acad. SCi. USA 75, 876-880.

Cohen F. S., Akabas M. H., and Finkelstein A. (1982) Osmotic swelling of phospholipid vesicles causes them to fuse with a planar phospholipid bilayer membrane. Science 217, $458-460$.

Douglas W. W. and Poisner A. M. (1961) Stimulation of uptake of calcium-45 in the adrenal gland by acetylcholine. Nature $162,1299$.

Dunn L. A. and Holz R. W. (1983) Catecholamine secretion from digitonin-treated adrenal medullary chromaffin cells. J. Biol. Chem. 258, 4989-4993.

Fabiato A. and Fabiato F. (1979) Calculator programs for computing the composition of the solutions containing multiple metals and ligands used for experiments in skinned muscle cells. J. Physiol. (Paris) 75, 463-505.

Fenwick E. M., Fajdiga B., Howe N. B. S., and Livett B. G. (1978) Functional and morphological characterization of isolated bovine adrenal medullary cells. J. Cell Biol. 76, $12-30$.

Frye R. A. and Holz R. W. (1985) Arachidonic acid release and catecholamine secretion from digitonin-treated chromaffin cells: effects of micromolar calcium, phorbol ester, and protein alkylating agents. J. Newrochem. 44, 265-273.

Hampton R. Y. and Holz R. W. (1983). The effects of osmolality on the stability and function of cultured chromaffin cells and the role of osmotic forces in exocytosis. J. Cell Biol. 96, $1082-1088$.

Holz R. W. and Senter R. A. (1985) Plasma membrane and chromaffin granule characteristics in digitonin-treated chromaffin cells. $J$. Neurochem. 45, 1548- 1557.

Holz R. W., Senter R. A., and Frye R. A. (1982) Relationship between $\mathrm{Ca}^{2+}$ uptake and catecholamine secretion in primary dissociated cultures of adrenal medulla. $J$. Netarochem. 39, 635-646.

Kachadorian W. A., Muller J., and Finkelstein A. (1981) Role of osmotic forces in exocytosis: studies of ADH-induced fusion in toad urinary bladder. J. Cell Biol. 91, 584-588.
Kilpatrick D. L., Ledbetter F. H., Carson K. A., Kirshner A. G., Slepetis R., and Kirshner N. (1980) Stability of bovine adrenal medulla cells in culture. $J$. Neurochem. 35 , 679-692.

Kilpatrick D. L., Slepetis R. J., Corcoran J. J., and Kirshner N. (1982) Calcium uptake and catecholamine secretion by cultured bovine adrenal medulia cells. $J$. Neurochem. 38 , 427-435.

Knight D. E. and Baker P. F. (1982) Calcium-dependence of catecholamine release from bovine adrenal medullary cells after exposure to intense electric fields. J. Membr. Biol. 68, $107-140$.

Knight D. E. and Kesteven N. T. (1983) Evoked transient intracellular free $\mathrm{Ca}^{2}+$ changes and secretion in isolated bovine adrenal medullary cells. Proc. R. Soc. Lond. [Biol.] 218, 177-199.

Kopell W. N. and Westhead E. W. (1982) Osmotic pressures of ATP and catecholamines relating to storage in chromaffin granules. J. Biol. Chem. 257, 5707-5710.

Lishajko F. (1970) Osmotic factors determining the release of catecholamines from isolated chromaffin granules. Acta Physiol. Scand. 79, 64-75.

Perlman R. L. (1976) The permeability of chromaffin granules to non-electrolytes. Biochem. Pharmacol. 25, 1035-1038.

Pollard H. B., Pazoles C. J., Creutz C. E., Scott J. H., Zinder O., and Hotchkiss A. (1984) An osmotic mechanism for exocytosis from dissociated chromaffin cells. J. Biol. Chem. 259, $1114-1121$.

Portzehl H., Caldwell P. C., and Ruegg J. C. (1964) The dependence of contraction and relaxation of muscle fibers from the crab Maia Squinado on the internal concentration of free calcium ions. Biochim. Biophys, Acta 79, 581-591.

Sen R. and Sharp R. R. (1982) Molecular mobilities and the lowered osmolality of the chromaffin granule aqueous phase. Biochim. Biophys. Acta 74, 70-82.

Sudhof T. C. (1982) Core structure, internal osmotic pressure and irreversible structural changes of chromaffin granules during osmometer behavior. Biochim. Biophys. Acta 684, $27-39$.

Wilson S. P. and Kirshner N. (1983) Calcium-evoked secretion from digitonin-permeabilized adrenal medullary chromaffin cells. J. Biol. Chem. 258, 4994-5000.

Zimmerberg J, and Whitaker M. (1985) Irreversible swelling of secretory granules during exocytosis caused by calcium. Nature 315, 581-584. 